\title{
Study and Practice of New Classroom Teaching Model Based on the Theory of Constructivism
}

\section{- Illustrated with the Course of Municipal Engineering Planning}

\author{
Shi-xia Zhang ${ }^{\text {a }}$, Shi-min Zhang ${ }^{\text {b1 }}$ \\ ${ }^{a}$ Department of Architecture Zhejiang Tongji Vocation College of Science and Technology, ZTVCST \\ Hangzhou, China \\ ${ }^{b}$ Department of Civil Engineering Zhejing University City College, ZUCC Hangzhou, China
}

\begin{abstract}
Based on the theory of constructivism and analysis of characteristics and mental types of students in vocation college, the new classroom teaching model is constructed. Illustrated with the course of municipal engineering planning the design and practice of classroom teaching were discussed and the theory of project planning was applied to the practice of teaching based on the new classroom teaching model reaching to better effect of teaching and learning.
\end{abstract}

Index Terms: Theory of constructivism; students in vocation college; new classroom teaching model; design and practice of classroom teaching; project planning

(C) 2012 Published by MECS Publisher. Selection and/or peer review under responsibility of the International Conference on E-Business System and Education Technology

\section{Introduction}

With its rich theoretical perspective and radical thinking, the theory of constructivism have impacted widely and profoundly on the field of education since the 20th century. Its education and learning concept, which challenges the traditional view of knowledge, learning and teaching, led to a practice revolution of educational concepts and serve as the main theoretical guidance of education reform in the 21 st century. Because the impact of the behavior theory, the traditional teacher-centered classroom emphasis on imparting knowledge[1]. This teaching model led to the lack of independence and autonomy of students and thinking ability weak. In the $21 \mathrm{st}$ century, the rapid development of higher vocational education, expanding education, the more complete of the school system, but the quality of teaching and the quality of personal training is not satisfactory. On the one hand, teachers focus on imparting knowledge in teaching, as most institutions born out of the original secondary vocational schools, some teachers are still accustomed to secondary education teaching. On the other hand, the poor foundation of the students and the lack of interest in learning, severely reduces the teaching quality and

Zhejiang New Century Education Reform Foundation(zc09086)

* Corresponding author: Shi-min Zhang

E-mail address: ' zhangsm@ zucc.edu.cn 
hinder the development of higher vocational education. Therefore, the correct understanding and analyzing the characteristics of higher vocational students, guided by constructivism, explore the new teaching mode and teaching method to make students from passive learning into active learning and to change the plight of the poor enthusiasm for study and the poor interactivity of classroom teaching. It has practical and long-term significance.

\section{Correctly understanding the characteristics of higher vocational students}

\section{A. Low cultural level, low self-esteem}

Higher vocational education is an important part of higher education. It is the vocational education of higher stage and its purpose is to train practical and technical talents. It has the dual properties of higher education and vocational education[1]. Higher vocational college students mainly come from high school graduates whose scores is lower than university fractional line, responsive students of secondary schools, vocational schools and technical school. Their cultural level is low and they also have a lot of difficulties in learning. Some students' understanding and receiving ability are weak. Due to higher vocational students belong to college level; they would have inferiority mentality compared with undergraduate students. Meanwhile, because of social bias against vocational, higher vocational students often prejudice about themselves, adding to their sense of inferiority.

\section{B. Lack of initiative, exploring and relation}

Many students' learning have no plan, they haven't paid attention to the connections of various disciplines. They can't grasp the whole subject. Due to the lack of inquiry, many students fail to appreciate the fun of learning. In many school libraries, although the facilities are available, and the learning environment is also very good, there are very few students to study or find information in the spare time. The students are forced to class, and they just finish the homework after class. Plagiarism is very serious. Lack of interest in learning and difficult to expand knowledge especially expertise knowledge limits the depth of learning.

\section{Active thinking, strong operating capacity, professional skills and adaptability}

Higher vocational students are not good as the students of colleges and universities, but they have a distinct advantage compared with vocational students. Such as their thinking is active and they are willing to show their own talent. They have accumulated a certain amount of knowledge and their thinking skills of observation and image has greatly improved. These indicate that they are better in undertaking complex mental work than secondary school students [2].

Higher vocational students have disadvantages in thought, learning and discipline, but they also have advantages. Higher vocational colleges should strengthen the research of teaching theory and students' learning psychology, meanwhile, teachers should adopt advanced teaching theory and method to stimulate the students' interest in study and improve the learning efficiency in the teaching process.

\section{Construction the new teaching mode adapt to higher vocational students}

Constructivism emphasizes that student-centered, teachers are the organizers, instructors, helpers and facilitators, students fully display the initiative and enthusiasm by using circumstances, cooperation, conversation etc learning environment factors. It eventually makes students effectively construct the current knowledge[3]. Therefore the characteristic of the classroom teaching is the students' active participation and active explore of knowledge. And because of higher vocational students' intelligence type with the characteristic of image thinking is "two-dimension" or even " $3 \mathrm{D}$ ", different from "one-dimension" logic thinking, and always related with the situation. It has a clear point of the selection of knowledge. It is good at gaining experience and strategy which is closely related with the specific situation. Obviously, based on this characteristic of intelligence, 
vocational education should mainly adopt situational teaching mode[4]. Under the guidance of constructivism theory, according to the characteristic of higher vocational students, based on the teaching experiences of "municipal engineering planning" a new classroom teaching mode is constructed (Fig1). It is proved that this model is feasible through several years practice.

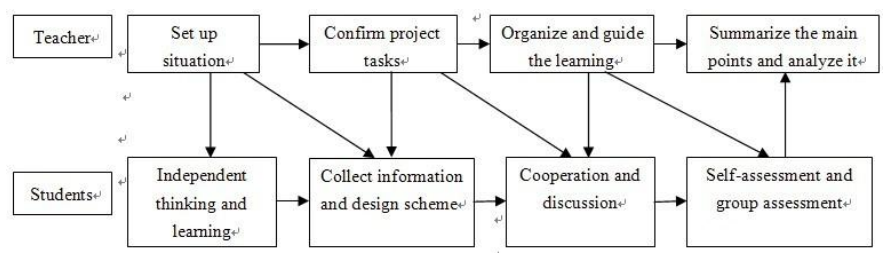

Fig 1 New classroom teaching mode flow

In the new classroom teaching mode, according to projects, teacher setting up the situation and discussion environment, students find their own way to solve the problem. Teacher leads student to analyze and to discuss the common problems in students' practical process. Students received vocational training in the simulation environment.

\section{The implementation of the new teaching mode}

In order to make the new teaching mode guide teaching practice, the author applied it to the teaching process in "Municipal Engineering Planning". In the new teaching mode, course design with the unit plan module includes four basic elements, namely topics, framework, implementing scheme and assessment gauges[5]. The unit plan, not traditional teaching units, but means a complete project based on the actual problems. It requires teacher to consider the whole course content or even subject-related knowledge. Arrangements for curriculum content must reflect the dominant position of students and fully consider the interaction between theory and practice. this paper takes "water supply facility planning" in "Municipal Engineering Planning" as an example.

\section{A. Unit theme and framework}

Unit theme is the study and research object of unit plan. It comes from the curriculum standards, academic content, practical problems and the combination of them above. The selection has been influenced by various factors. At first, it has been influenced by the designer's own interest and best, and the learner is one of the effect factors, too. The designer should determine the theme according to the students' actual situation. The design of framework is the core of unit plan. Its role is to frame the scope of unit learning, and guide students to learn and explore further. Framework place students in a meaningful situation, and students play inquirer who is responsibility to analysis and solve problems. Framework is a group-level problems, it consists of basic issue, unit issue and content issue. They are interrelated and jointly point Unit Plan. The following is the unit theme and framework of "water supply facility planning" unit plan.

"Water supply facility planning" unit plan

Teaching Target: Sophomore

Subject: Town Planning

Theme: Water supply facility planning

Learning Focus: Mastering the content of water supply facilities planning, methods of forecasting water discharge, water treatment methods and process and the types of water resource

Hours: 1 week, 6 periods every week 
"WATER SUPPLY FACILITY PLANNING" UNIT PLAN

\begin{tabular}{|c|c|c|}
\hline \multicolumn{2}{|c|}{ Unit Title } & Water Supply Facility Planning \\
\hline \multirow{11}{*}{$\begin{array}{l}\text { Framewor } \\
\mathrm{k}\end{array}$} & Basic issue & What is the content of "water supply facility planning"? \\
\hline & \multirow{4}{*}{ Unit issue } & 1 What are the water treatment methods commonly used? \\
\hline & & 2 What are the types of water structures? \\
\hline & & $\begin{array}{l}3 \text { What is the water treatment process in your hometown? } \\
\text { What process has been contained? }\end{array}$ \\
\hline & & 4 What factors determine the water treatment process? \\
\hline & \multirow{6}{*}{$\begin{array}{l}\text { Content } \\
\text { issue }\end{array}$} & 1 How about the water status on the ground? \\
\hline & & $\begin{array}{l}2 \text { How about the situation of water pollution? What are the } \\
\text { main sources of pollution? }\end{array}$ \\
\hline & & $\begin{array}{l}3 \text { How about the current status of hometown drinking water? } \\
\text { How much is the popularity rate of tap water? }\end{array}$ \\
\hline & & $\begin{array}{l}4 \text { What are the types of water? What are the respective } \\
\text { characteristics of them? }\end{array}$ \\
\hline & & 5 How to predict water content? \\
\hline & & 6 What is the conventional process of water treatment? \\
\hline
\end{tabular}

From the above, we know that the theme of unit is not closed but open. It comes from the vast world of life. It also has investigative. For example, the unit theme "water supply facility planning" is not to directly describe the contents of water supply and water treatment methods, but to offer students the answers by explorative ways after doing social surveys, collecting, analyzing and summering information in the real life.

The basic issue of the framework is the most abstract. It is the frame of the frameworks. As the core problem of unit theme, it dominates the unit issue and content issue. It is an attractive, meaningful, investigative and controversial problem. The unit issue is different aspects of it, which is the bridge between basic issue and content issue. The basic features of unit issue are as follows: Under the frame of basic issue, it supports the basic issue; it is open to contact the student's personal world; It can stimulate students to explore. And that content issue refers to the factual knowledge and basic skills problems; it solves the problem about "What".

\section{B. Implementation of the program}

The third element of unit plan is to implement the program.It refers to concrete steps of implementing unit plan. It generally includes 3 steps, which are knowledge preparation, subject research, results communication and exhibition. It mainly based on the idea of the instructor, and it just like a micro research approach. The following table 2 is the concrete steps of implementing unit plan about "water supply facility planning".

Implementation plan is the Concrete steps putting unit plan into practice. It is not to prepare lessons traditionally, but to develop a program of activities with the generation, open and dynamic characteristics. In the course, learners lead the whole unit plan to carry out. As the implementation process of the "support", teachers play the role of guiding and monitoring. Learners gain knowledge and experience by participating in social surveys and discussions personally. In fact, it is bore easier to combine with real life, and more practical for learners.

The fourth element of unit plan is to evaluate the gauge. The so-called gauge refers to the evaluation questionnaires of student learning results (research results) after the implementation of the research. These valuation questionnaires should reflect the basic idea of evaluation's expansibility. To evaluate students' learning 
results aim at promoting them to further improve. The key of making a evaluation questionnaire is to subdivide the learning outcomes and to determine the evaluation index system. It is not to measure or test the level of learners' mastering knowledge, but to provide students with a self-examination thread. Allow students to check up their learning process across-the-board. Then, they can summary the experiences and lessons they have learned during researching and learning.

TABLE II. THE IMPLEMENTING OF "WATER SUPPLY FACILITY PLANNING" UNIT PLAN

\begin{tabular}{|l|l|}
\hline \multicolumn{1}{|c|}{ Process and time } & \multicolumn{1}{c|}{ Working content } \\
\hline $\begin{array}{l}\text { The first step } \\
\text { 1 period (before } \\
\text { class) } \\
\text { (Notes: Gave the } \\
\text { students 4 weeks to } \\
\text { collect and collate } \\
\text { information, writing } \\
\text { report and } \\
\text { courseware during } \\
\text { holidays and spare } \\
\text { time.) }\end{array}$ & $\begin{array}{l}\text { Assigning tasks, Sending the questionnaires, Creating the scenarios, } \\
\text { and Stimulating students' interest. } \\
\text { Tell students to make incipient preparation of research knowledge } \\
\text { through autonomic research. Such as requiring students to do several } \\
\text { social surveys before class(during holidays),asking them to see the } \\
\text { water environment of theirs' hometown, doing further investigation on } \\
\text { the waterworks, and then collecting information on water treatment } \\
\text { methods and techniques by network resources and information } \\
\text { technology, and so on. }\end{array}$ \\
\hline The second step & $\begin{array}{l}\text { Investigating the reasons by group discussions. } \\
\text { To divide the students into several groups, ask each group as a team to } \\
\text { discuss on following questions: } \\
\text { 1 What are the types of water? What are the respective characteristics } \\
\text { of them? 2 What are the types of water structures?3 What are the water } \\
\text { treatment methods commonly used? } 4 \text { What is the conventional } \\
\text { process of water treatment? 5 How to determine the water supply scale } \\
\text { of waterworks? } \\
\text { Improving their investigation reports and presentations after } \\
\text { discussing. }\end{array}$ \\
\hline periods & $\begin{array}{l}\text { Exchanging and discussing. } \\
\text { Improving each group's presentations after Panel discussion. Ask the } \\
\text { representatives of every team to speak and communicate with each } \\
\text { other. } \\
\text { Teachers guide students to think from multiple perspectives: } \\
\text { What factors determine the process of water treatment? } \\
\text { Holding a discussing on the comment of the previous survey, explore } \\
\text { and learning. Representatives summarize the measures of team which } \\
\text { they belongs to. Scoring for the team on the spot. }\end{array}$ \\
\hline $\begin{array}{l}\text { Summarizing, concluding and evaluating: } \\
\text { Teachers make summary and evaluation based on the students' social } \\
\text { survey, discuss and communion. Make the students' knowledge from } \\
\text { practice to theory. It is good for them to understand and construct } \\
\text { knowledge system that they have learned. }\end{array}$ \\
\hline period
\end{tabular}

Through the course design and implementation procedures, we can see: In the new teaching mode, it is fully reflected that the students' dominant learning position and the teachers' "teaching" guidance role. The teachers subdivision the learning target, and then stimulate the student to learn. The learners are actively to participate 
and willing to explore, diligently to work by creating scenarios, social surveys, discussions and exchange and constructing the learning environment. It can cultivate the students' abilities, such as the ability to collect and process information, acquire new knowledge, analysis and solve problems, and communicate and cooperate with others. Constructivism theory is that: compares to individual learning learners can share a greater understanding and meaning by group. They can accomplish certain tasks and solve some problems together by communication, argument and discussion, and then formatting a richer, more flexible understanding[6]. In the new teaching mode, classroom teaching greatly aroused the enthusiasm of learners. The student's perceptual knowledge can be fully combined with rational knowledge. So, classroom teaching and learning can achieve very successful results. Fig 2 are some pictures material from students' social investigation.
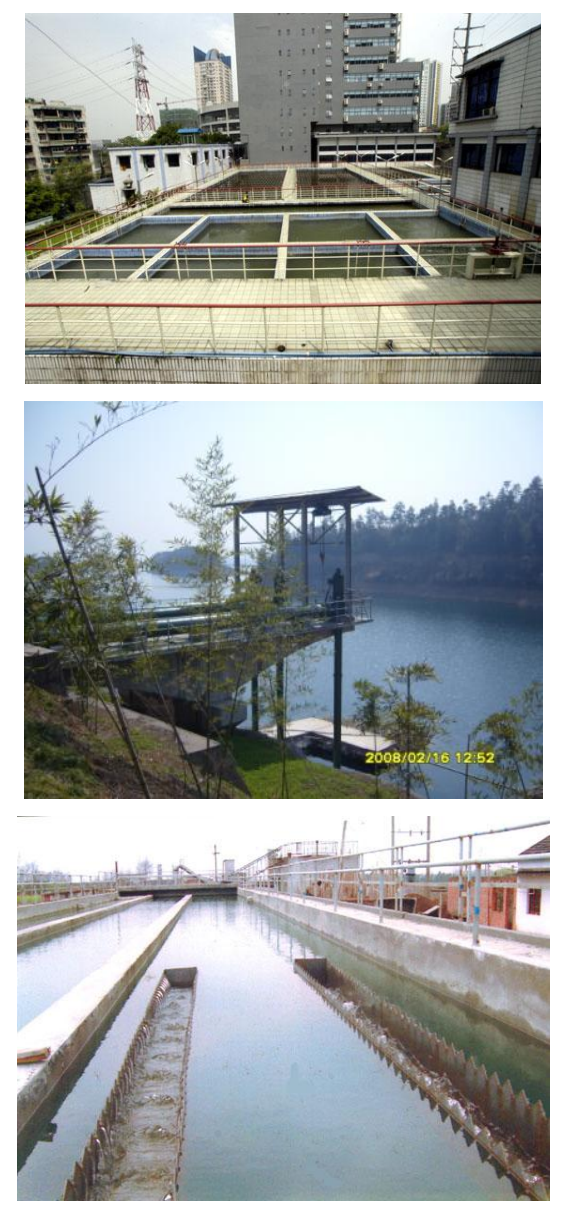

Fig 2 Water treatment facilities of Waterworks (From students' social survey )

\section{Conclusion}

In short, under the guidance of constructivist theory, the new teaching model should be: the students are the center of the learning process, and the teachers play an organizing and coordinating role. There should be enough interaction between teachers and students in classroom teaching. Through "obtaining information independently, formulating plans independently, implementing plans independently, evaluating plans independently ", the students can grasp the professional knowledge and skills, accumulate experience, and then construct knowledge 
system which belong to themselves. Note that constructivism emphasizes student-centered, but it does not mean to ignore the teachers whose guide and help is extremely important for the students to think and construct knowledge[7]. In the new teaching mode, the teachers should convert their roles successfully. They are not only the initiators or indoctrinators, but also the designers, organizers and guides of classroom teaching. It is flexible in the actual operation. If necessary, the time, ways and methods can be changed according to different course and content.

\section{References}

[1] XIN Zhi-qiang. Research in knowledge construction. From socialism to empirical[M]. Beijing: Education Science Press, 2006, 7 (in Chinese) .

[2] WU Jing. Characteristics of higher vocational students and teaching methods for them[J]. Northwest Medical Education, 2006, (21) (in Chinese).

[3] ZHANG Hong-yan. Research in constructivism teaching method from the perspective of structure model[J]. Modern Education Technology, 2007, 17(2): 13-15(in Chinese).

[4] JIANG Da-yuan. Thinking about the problem of vocational education ( II )[J]. Vocational and Technical Education (EDUCATION), 2006, 27(4): 4-11(in Chinese).

[5] AI Xin. Constructivism curriculum research. PhD thesis, University of Southwest, 2007, 4 (in Chinese) .

[6] HE Ke-kang. Constructivist teaching mode, teaching method and teaching design[J]. Journal of Beijing Normal University (Social Sciences), 1997, 5 (in Chinese).

[7] WU Nan. Revelation of constructivism for teaching reform[J]. Journal of Liaoning Institute of Science, 2005, 12(in Chinese). 